Formatif: Jurnal Ilmiah Pendidikan MIPA

Vol. 9, No. 3, September 2019, pp. 219-228

p-ISSN: 2088-351X

e-ISSN: 2502-5457

DOI: http://dx.doi.org/10.30998/formatif.v9i3.3638

\title{
The Effect of Using POE-Based Worksheet on Student's Learning Outcomes in Material of Impulses and Momentum
}

\author{
Pengaruh Penggunaan LKPD Berbasis Predict Observe Expalain (POE) terhadap \\ Hasil Belajar Peserta Didik Materi Impuls dan Momentum
}

\author{
Dwi Kusdayanti (*) \\ Universitas Lampung \\ I Dewa Putu Nyeneng \\ Universitas Lampung \\ Nengah Maharta \\ Universitas Lampung
}

Received: April 22, 2019

Revised: July 19, 2019

Accepted: August 12, 2019

\begin{abstract}
This study aims to determine the effect of using POE-based worksheets on student's learning outcomes of physics in material of impulses and momentum at SMAN 5 Bandar Lampung. The research population was all students of class X MIA. The design of this study uses True Experimental Design with a Pretest Posttest Control Group Design type. The research sample in this study was class X MIA 1 and $\mathrm{X} \mathrm{MIA}_{2}$ with relatively similar initial abilities so that the Simple Purposive Sampling technique was used. The independent sample t-test results showed a significance value of 0,000 for cognitive, psychomotor learning outcomes through questions and through practical performance so that the use of POE-based worksheets on impulse and momentum material had a significant effect on student learning outcomes. The magnitude of the effect obtained from the results of the effect size test (Cohen d) is 2,18 for the cognitive domain; 1,34 and 1,21 for the psychomotor domain (high category). This means that the use of POE-based woeksheets in this study has a large effect on student learning outcomes.
\end{abstract}

Keywords: Learning outcomes, POE, Student worksheets, Impulses and momentum.

(*) Corresponding Author: $\quad \underline{\text { dwikusdayanti@gmail.com }}$

How to Cite: Kusdayanti, D., Nyeneng, I.D.P., \& Maharta, N. (2019). The effect of using poe-based worksheet on student's learning outcomes in material of impulses and momentum. Formatif: Jurnal Ilmiah Pendidikan MIPA, 9 (3): 219-228. http://dx.doi.org/10.30998/formatif.v9i3.3638

\section{PENDAHULUAN}

Pembelajaran merupakan suatu proses interaksi antara pendidik, peserta didik, serta sumber belajar pada suatu lingkungan belajar. Pembelajaran yang efektif dapat terwujud apabila pengetahuan, ilmu, maupun konsep yang ingin dibelajarkan dapat tersampaikan dengan baik kepada peserta didik. Banyak faktor yang dapat mempengaruhi terwujudnya proses pembelajaran efektif, salah satunya adalah media pembelajaran yang digunakan oleh pendidik (Sisdiknas, 2003). Pembelajaran yang efektif tidak hanya bergantung pada pendidik, tapi juga pada peserta didiknya. Peserta didik harus bertindak secara aktif, tidak hanya sekadar menerima ilmu secara pasif dari guru mereka. Pembelajaran yang aktif 
Formatif: Jurnal Ilmiah Pendidikan MIPA

Vol. 9, No. 3, September 2019, pp. 219-228

p-ISSN: 2088-351X

e-ISSN: 2502-5457

DOI: http://dx.doi.org/10.30998/formatif.v9i3.3638

merupakan pembelajaran yang melibatkan peserta didik secara aktif saat proses pembelajaran berlangsung. (Astuti, Sulianto, \& Purnamasari, 2018)

Proses pembelajaran sekarang mulai beralih pada proses pembelajaran abad 21 . Hal ini mengharuskan peserta didik memiliki literasi dalam penggunaan teknologi informasi dan juga media berbasis teknologi digital (Astuti et al, 2019). Pada proses pembelajaran ini, salah satu strategi pencapaiannya yaitu materi ajar dan media yang diberikan harus kontekstual (Badan Standar Nasional Pendidikan, 2010). Dalam hal ini, media pembelajaran sangat berpengaruh terhadap kondisi kognitif peserta didik. Peserta didik akan lebih mudah menggambarkan kejadian atau hal yang faktual dibandingkan dengan membayangkan sesuatu yang bersifat abstrak (Mahnun, 2012).

Salah satu inovasi yang dapat diterapkan adalah dengan penggunaan media yang dapat membantu terwujudnya tujuan pembelajaran. Terdapat berbagai macam media pembelajaran, salah satunya yang sering digunakan adalah lembar kerja peserta didik (LKPD). Peserta didik yang menggunakan LKPD mengalami peningkatan hasil belajar kognitif dan pemahaman konsep yang lebih tinggi daripada peserta didik yang mendapatkan pembelajaran tanpa LKPD (Ristiyani \& Yulianti, 2014). LKPD juga dipilih karena harganya yang lebih terjangkau dan efisien. LKPD yang digunakan di sekolah saat ini tidak melatih peserta didik untuk melakukan proses penyelidikan karena hanya berisi kumpulan soal yang harus dikerjakan (Mayasari, Syamsurizal, \& Maison, 2015). LKPD yang hanya berisi ringkasan materi dan latihan soal tidak melatih peserta didik untuk melakukan penyelidikan dan pengembangan nilai konservasi (Yulianti, Marfu'ah, \& Yulianto, 2015). Sementara itu, LKPD juga merupakan salah satu bahan ajar yang penting untuk tercapainya keberhasilan dalam pembelajaran fisika (Yanti, Arcat, \& Hardianto, 2013). LKPD harus memenuhi kriteria yang berkaitan dengan tercapai atau tidaknya sebuah kompetensi oleh peserta didik. LKPD dibuat dengan tujuan untuk membantu peserta didik menemukan suatu konsep, baik melalui praktikum maupun teori, dan membantu peserta didik menerapkan serta mengintegrasikan berbagai konsep yang telah ditemukan (Permatasari, Nyeneng, \& Wahyudi, 2018).

LKPD berbasis $P O E$ merupakan lembar kerja yang di dalamnya terdapat langkahlangkah $P O E$. Pembelajaran $P O E$ diketahui efektif bagi guru dalam memahami sejauh mana pengamatan dan hasil prediksi yang dikemukakan oleh peserta didik (Liew \& Treagust, 2004). Berikut penjelasan langkah-langkah pembelajaran berbasis $P O E$.

1. Memprediksi (Predict)

Pada tahap ini, peserta didik memprediksi/meramalkan peristiwa yang akan terjadi terhadap suatu permasalahan yang diinformasikan oleh guru. Penyusunan prediksi/ramalan berdasarkan pengetahuan awal, pengalaman, atau buku yang pernah mereka baca berkaitan dengan permasalahan pada materi impuls dan momentum. Prediksi/ramalan tersebut ditulis pada selembar kertas dan dikumpulkan kepada guru.

2. Mengamati (Observe)

Selanjutnya, peserta didik dalam kelompok kecil (4-5 anak) melakukan percobaan (praktikum) berkaitan dengan permasalahan pada materi impuls dan momentum yang telah diinformasikan guru kemudian mengamati hasil percobaan untuk menguji kebenaran prediksi/ramalan yang telah dibuat peserta didik sebelumnya. Percobaan dilaksanakan dengan bimbingan guru sesuai langkah/prosedur kerja yang ditetapkan pada lembar kerja peserta didik.

3. Menjelaskan (Explain)

Setelah melakukan percobaan pada pokok bahasan impuls, momentum, tumbukan dan hukum kekekalan momentum dengan prosedur yang benar, peserta didik dalam kelompok kecil (4-5 anak) menuliskan hasil percobaan dan menyusun hipotesis atas hasil 
Formatif: Jurnal Ilmiah Pendidikan MIPA

Vol. 9, No. 3, September 2019, pp. 219-228

p-ISSN: 2088-351X

e-ISSN: 2502-5457

DOI: http://dx.doi.org/10.30998/formatif.v9i3.3638

percobaan tersebut. Selanjutnya mereka menjelaskan perbedaan yang terjadi antara prediksi awal mereka dengan hasil percobaan yang dilakukan.

Hal-hal yang perlu diperhatikan dalam pembelajaran $P O E$ adalah: a) masalah yang diajukan sebaiknya masalah yang memungkinkan terjadi konflik kognitif dan memicu rasa ingin tahu; b) prediksi harus disertai alasan yang rasional dan bukan sekadar menebak; c) demonstrasi atau eksperimen harus bisa diamati dengan jelas, dan dapat memberi jawaban atas masalah; peserta didik dilibatkan dalam proses eksplanasi (Gustina, Fadiawati, Kadaritna, \& Diawati, 2013). Dalam sebuah penelitian diketahui bahwa $P O E$ memberi daya tarik kepada peserta didik dan membuat mereka menyadari kesalahan konsep yang mereka alami dengan observasi (Keleş \& Demirel, 2010). Pembelajaran dengan langkah $P O E$ membuat peserta didik aktif bertanya dan berguna dalam menghilangkan miskonsepsi siswa (Ipek, 2010).

Hasil belajar siswa merupakan suatu hasil akhir yang diperoleh oleh peserta didik dari proses memahami dan mengamati suatu pembelajaran yang diberikan. Hasil belajar dapat mengungkap penggambaran pencapaian peserta didik setelah melalui pembelajaran secara holistik (Sutrisno \& Siswanto, 2016). Pada saat proses belajar itu dilakukan, maka akhir rangkaian proses tersebut dapat menghasilkan suatu bentuk perubahan yang nampak pada diri peserta didik sebagai hasil belajar. Hal ini sesuai dengan hasil penelitian (Fadly, 2012) bahwa hasil belajar berfungsi sebagai petunjuk tentang perubahan tingkah laku yang akan dicapai oleh peserta didik sehubungan dengan kegiatan pembelajaran yang dilakukan. Hasil belajar diartikan sebagai suatu yang dicapai oleh seseorang dengan adanya perubahan-perubahan dalam dirinya baik perubahan secara berpikir dan bertindak dalam ranah pengetahuan (kognitif), sikap (afektif), dan keterampilan (psikomotor) setelah seseorang tersebut mengalami suatu proses belajar. Berdasarkan uraian di atas, penelitian ini bertujuan untuk melihat pengaruh penggunaan LKPD berbasis $P O E$ terhadap hasil belajar peserta didik. Hasil belajar dalam penelitian ini dibatasi untuk hasil belajar ranah kognitif dan psikomotorik.

Berdasarkan hasil observasi guru dan peserta didik di SMAN 5 Bandarlampung, pembelajaran yang dilakukan di dalam kelas menggunakan LKPD konvensional. LKPD yang digunakan di sekolah sudah memuat salah satu kegiatan percobaan dari beberapa submateri yang disajikan. Namun, pembelajaran di dalam kelas hanya melakukan simulasi yang berkaitan dengan percobaan tersebut. Pembelajaran pun cenderung tidak terarah sehingga sering terjadi miskonsepsi. Akibatnya peserta didik belum cukup mampu mengembangkan keterampilan psikomotoriknya dan menyebabkan proses berpikir peserta didik dalam konstruksi kognitif berkurang.

Pembelajaran berbasis $P O E$ telah banyak digunakan untuk meningkatkan pemahaman konsep serta miskonsepsi peserta didik. Namun, pengaruh pembelajaran dengan strategi $P O E$ terhadap hasil belajar kognitif dan juga psikomotorik belum banyak diungkapkan. Oleh sebab itu, dilakukan penelitian dengan menerapkan pembelajaran menggunakan LKPD yang belum pernah diterapkan oleh sekolah yaitu penggunaan LKPD berbasis $P O E$ guna melihat pengaruhnya terhadap hasil belajar kognitif dan psikomotorik peserta didik.

\section{METODE}

Desain penelitian ini menggunakan True Experimental Design dengan jenis Pretest Posttest Control Group Design (Tabel 1), yakni satu kelompok subyek diberi perlakuan tertentu (eksperimen), sementara satu kelompok lain dijadikan sebagai kelompok kelas kontrol. Desain penelitian ini terdapat pretest sebelum diberi perlakuan 
Formatif: Jurnal Ilmiah Pendidikan MIPA

Vol. 9, No. 3, September 2019, pp. 219-228

p-ISSN: 2088-351X

e-ISSN: 2502-5457

DOI: http://dx.doi.org/10.30998/formatif.v9i3.3638

dan posttest setelah diberi perlakuan. Kelas eksperimen diberi perlakuan menggunakan LKPD berbasis $P O E$, sedangkan kelas kontrol menggunakan LKPD yang biasa digunakan di sekolah. Hasil pretest dan posttest pada kedua kelas subyek dibandingkan.

Tabel 1. Desain Penelitian

\begin{tabular}{lccc}
\hline Kelas & Pretest & Perlakuan & Posttest \\
\hline Eksperimen & $\mathrm{O} 1$ & $\mathrm{X}_{1}$ & $\mathrm{O}_{3}$ \\
Kontrol & $\mathrm{O} 2$ & $\mathrm{X}_{2}$ & $\mathrm{O}_{4}$ \\
\hline
\end{tabular}

Populasi penelitian ini adalah seluruh siswa kelas X MIA di SMAN 5 Bandar Lampung tahun ajaran 2018/2019. Pengambilan sampel penelitian pada populasi kelas X MIA dilakukan dengan teknik Simple Purposive Sampling, di mana dipilih 2 kelas dari 6 kelas yaitu kelas $\mathrm{X}_{\mathrm{MIA}}$ sebagai kelas eksperimen dan X MIA 2 sebagai kelas kontrol. Kelas tersebut merupakan kelas yang memiliki kemampuan yang relatif sama. Instrumen yang digunakan berupa silabus, Rencana Perencanaan Pembelajaran (RPP), LKPD, instrumen soal kognitif maupun psikomotorik, serta instrumen kinerja praktikum peserta didik.

Kelas eksperimen diberi perlakuan dengan menggunakan LKPD berbasis $P O E$ sedangkan kelas kontrol menggunakan LKPD yang biasa dipergunakan di sekolah. Teknik pengumpulan data yang digunakan dalam penelitian ini menggunakan tes tertulis berbentuk uraian yang digunakan pada saat pretest dan posttest ranah kognitif dan psikomotorik, serta lembar penilaian kinerja praktikum. Langkah yang dilakukan dalam pengumpulan data adalah pemberian tes awal kepada seluruh siswa sebelum pembelajaran (pretest), melakukan pembelajaran menggunakan LKPD berbasis POE pada kelas eksperimen dan LKPD yang biasa digunakan di sekolah pada kelas kontrol, melakukan tes di akhir pembelajaran (posttest), serta penilaian saat melakukan kegiatan observasi melalui lembar kinerja praktikum.

Data hasil belajar pretest dan posttest akan dianalisis menjadi skor $\mathrm{N}$-Gain yang diperoleh melalui persamaan (Meltzer, 2002):

$$
N-\operatorname{gain}(g)=\frac{S_{\text {post }}-S_{\text {pre }}}{S_{\max }-S_{\text {pre }}}
$$

Keterangan:

$$
\begin{array}{ll}
\mathrm{g} & =N \text {-gain } \\
\text { Spost } & =\text { Skor posttest } \\
\text { Spre } & =\text { Skor pretest } \\
S_{\max } & =\text { Skor maksimum }
\end{array}
$$

Setelah diperoleh skor gain ternormalisasi, selanjutnya dilakukan uji independent sample t-tes dengan program SPSS versi 20 untuk menguji hipotesis apakah terdapat perbedaan antara masing-masing hasil belajar siswa menggunakan LKPD berbasis $P O E$ dan LKPD yang biasa digunakan di sekolah. Besarnya pengaruh yang dihasilkan akan dianalisis menggunakan uji effect size. Effect size dihitung dengan menggunakan nilai mean dan standar deviasi yang telah diperoleh melalui independent sample t-test. Penelitian ini memperoleh nilai standar deviasi yang berbeda antara kelas eksperimen dan kelas kontrol sehingga effect size-nya dapat diketahui menggunakan persamaan (Cohen, 1988): 
Formatif: Jurnal Ilmiah Pendidikan MIPA

Vol. 9, No. 3, September 2019, pp. 219-228

p-ISSN: 2088-351X

e-ISSN: 2502-5457

DOI: http://dx.doi.org/10.30998/formatif.v9i3.3638

$$
d=\frac{\left|M_{a}-M_{b}\right|}{\sqrt{\frac{\sigma_{a^{2}}+\sigma_{b^{2}}}{2}}}
$$

Keterangan :

$M_{a}=$ Mean kelas eksperimen

$M_{b}=$ Mean kelas kontrol

$\sigma_{a^{2}}=$ Standar deviasi kelas eksperimen

$\sigma_{b^{2}}=$ Standar deviasi kelas kontrol

Kriteria nilai d besari jika $0,8<\mathrm{d}<2,0$; rata-rata jika $0,5<\mathrm{d}<0,8$; dan dan kecil jika $0,2<\mathrm{d}<0,5$.

\section{HASIL DAN PEMBAHASAN}

\section{Hasil}

Penelitian dimaksudkan untuk menjawab rumusan masalah yaitu ada atau tidaknya pengaruh terhadap hasil belajar yang diakibatkan oleh penggunaan LKPD berbasis $P O E$ pada materi impuls dan momentum di dalam kelas. Nilai rata-rata $\mathrm{N}$-gain hasil belajar ranah kognitif maupun psikomotorik pada kelas eksperimen memiliki nilai yang lebih tinggi dengan rata-rata $\mathrm{N}$-gain kelas kontrol. Rata-rata $\mathrm{N}$-gain hasil belajar kognitif dan psikomotorik dapat dilihat pada Tabel 2.

Tabel 2. Rata-Rata N-gain Hasil Belajar

\begin{tabular}{cccc}
\hline Hasil Belajar & Kelas & Rata-rata $N$-Gain & Kategori \\
\hline Kognitif & Eksperimen & 0,77 & Tinggi \\
& Kontrol & 0,53 & Sedang \\
Psikomotorik & Eksperimen & 0,80 & Tinggi \\
& Kontrol & 0,60 & Sedang \\
\hline
\end{tabular}

Penilaian hasil belajar peserta didik ranah psikomotorik tidak hanya menggunakan soal pretest dan posttest, tetapi juga menggunakan lembar penilaian kinerja praktikum. Kinerja praktikum peserta didik diukur menggunakan instrumen kinerja dengan pengamatan yang dilakukan secara langsung oleh peneliti saat peserta didik melakukan tahap percobaan. Rata-rata hasil kinerja praktikum peserta didik dapat dilihat pada Tabel 3 .

Tabel 3. Hasil Kinerja Praktikum

\begin{tabular}{cccc}
\hline Kelas & Nilai & Huruf Mutu & Tingkat Pencapaian \\
\hline Eksperimen & 81,85 & B & Baik \\
Kontrol & 73,58 & B & Baik \\
\hline
\end{tabular}

Setelah mengetahui hasil dari uji $\mathrm{N}$-gain, dan kinerja praktikum, selanjutnya diuji dengan menggunakan uji independent sampel t-test untuk mengetahui penggunaan LKPD berbasis $P O E$ memiliki pengaruh atau tidak. Hasil uji independent sample t-test disajikan pada Tabel 4. 
Formatif: Jurnal Ilmiah Pendidikan MIPA

Vol. 9, No. 3, September 2019, pp. 219-228

p-ISSN: 2088-351X

e-ISSN: 2502-5457

DOI: http://dx.doi.org/10.30998/formatif.v9i3.3638

Tabel 4. Hasil Uji Independent Sample T-Test dan Effect Size

\begin{tabular}{llll}
\hline Hasil Belajar & Bentuk Tes & Asymp. Sig (2-tailed) & Effect Size (Cohen's d) \\
\hline Kognitif & Soal Uraian & 0,000 & 2,18 \\
Psikomotorik & Soal Uraian & 0,000 & 1,34 \\
& Kinerja & 0,000 & 1,21 \\
& Praktikum & & \\
\hline
\end{tabular}

Pembahasan

Berdasarkan Tabel 2 dapat dilihat bahwa rata-rata $N$-gain hasil belajar kognitif maupun psikomotorik kelas eksperimen adalah 0,77 dan 0,80 dengan kategori tinggi dan $N$-gain kelas kontrol diperoleh nilai sebesar 0,53 untuk ranah kognitif dan 0,60 dengan kategori sedang untuk ranah psikomotorik. Artinya, LKPD berbasis $P O E$ yang digunakan pada kelas eksperimen memberikan peningkatan yang lebih baik pada hasil belajar siswa dibandingkan dengan LKPD yang biasa digunakan guru. Berdasarkan Tabel 3 dapat dilihat bahwa kinerja praktikum peserta didik baik kelas eksperimen maupun kontrol memiliki tingkat pencapaian kinerja praktikum dengan predikat "Baik". Peserta didik menampilkan kinerja yang baik dan menunjukkan peningkatan secara umum. Akan tetapi pencapaian kinerja praktikum pembelajaran kelas eksperimen sebesar 81,85 lebih tinggi dibandingkan kelas kontrol 73,58.

Berdasarkan Tabel 4 dapat dilihat bahwa uji t pada soal uraian ranah kognitif memiliki nilai asymp. sig. (2-tailed) sebesar 0,000. Begitu pula soal uraian psikomotorik dan kinerja praktikum memiliki nilai asymp. sig. (2-tailed) sebesar 0,000 dan 0,000. Karena nilai asymp. sig. (2-tailed) ranah kognitif dan psikomotorik lebih kecil dari 0,050; maka dapat disimpulkan bahwa $\mathrm{H}_{0}$ ditolak dan $\mathrm{H}_{1}$ diterima, sehingga pembelajaran menggunakan LKPD berbasis $P O E$ berpengaruh terhadap hasil belajar peserta didik pada ranah kognitif dan psikomotorik. Besarnya pengaruh yang dihasilkan dapat diuji menggunakan uji interpretasi effect size. Hasil interpretasi effect size (nilai cohen's d) hasil belajar kognitif, tes psikomotorik, dan kinerja praktikum yang diperoleh dari perhitungan yaitu sebesar 2,18; 1,34; dan 1,21 dengan kriteria keseluruhan besar. Sehingga dapat dikatakan bahwa penggunaan LKPD berbasis POE pada penelitian ini berpengaruh besar terhadap hasil belajar peserta didik.

Pengaruh dan perbedaan rata-rata $N$-gain hasil belajar tersebut diperoleh karena pada kelas eksperimen menggunakan LKPD berbasis $P O E$ yang di dalamnya terdapat langkah-langkah pembelajaran $P O E$. Hal tersebut dibuktikan oleh penelitian (Berek, 2016) bahwa pembelajaran menggunakan strategi $P O E$ dapat meningkatkan pemahaman konsep, sehingga berpengaruh terhadap hasil belajar peserta didik dengan nilai effect size sebesar 1,61 (sangat tinggi). Hal tersebut juga relevan dengan penelitian yang telah dilakukan (Erni, Napitupulu, \& Sakung, 2013) yang menyimpulkan bahwa pembelajaran $P O E$ berpengaruh terhadap hasil belajar, karena dapat memberikan peningkatan minat belajar dan hasil belajar siswa dengan ketercapaian nilai $71,42 \%$.

Pembelajaran dengan model $P O E$ melibatkan peserta didik secara langsung dalam melakukan aktivitas dan menumbuhkan sikap ilmiah karena dalam pembelajarannya melalui tiga langkah utama metode ilmiah yaitu predict atau memprediksi, observe atau mengamati guna menguji hasil prediksi, dan explain atau menjelaskan proses awal hingga akhir pembelajaran. Melalui langkah kegiatan tersebut mampu merangsang peserta didik untuk lebih kreatif khususnya pada saat merumuskan prediksi. Proses pembelajaran menjadi lebih menarik, sebab peserta didik tidak hanya mendengarkan tetapi juga mengamati peristiwa yang terjadi melalui observasi sehingga peserta didik memiliki kesempatan untuk membandingkan antara teori (dugaan) dengan 
Formatif: Jurnal Ilmiah Pendidikan MIPA

Vol. 9, No. 3, September 2019, pp. 219-228

p-ISSN: 2088-351X

e-ISSN: 2502-5457

DOI: http://dx.doi.org/10.30998/formatif.v9i3.3638

kenyataan. Dengan demikian, peserta didik lebih meyakini kebenaran materi pembelajaran. Hal tersebut sejalan dengan hasil penelitian (Cinici \& Demir, 2015) bahwa pembelajaran $P O E$ digunakan untuk merencanakan kegiatan pembelajaran berbasis perubahan konseptual yang efektif dalam kelompok dan menjadikan pembelajaran menjadi lebih aktif. Perubahan konseptual yang dimaksud adalah ketika peserta didik mengkritisi prediksi awalnya sendiri berdasarkan hasil observasi yang telah dilaksanakan. Begitu pula dalam penelitian (Puspitasari, Lesmono, \& Prihandono, 2015) yang menunjukkan bahwa dengan menggunakan pembelajaran $P O E$ terutama pada tahap observasi melalui eksperimen peserta didik menjadi lebih aktif dalam pembelajaran. Penelitian yang dilakukan (Rifzal, Akmam, \& Nurhayati, 2015) menyatakan bahwa penggunaan LKPD berbasis POE menjadikan siswa terlatih untuk menyelesaikan suatu persoalan menggunakan metode ilmiah. Selain itu, dalam pembelajaran menggunakan langkah $P O E$ peserta didik diberi kebebasan untuk memprediksi, mengamati, menganalisis, dan menarik kesimpulan sendiri sehingga keterampilan peserta didik juga akan lebih terlihat optimal (Rosdianto, Murdani, \& Hendra, 2017).

\section{PENUTUP}

Berdasarkan hasil penelitian dan pembahasan, maka dapat ditarik simpulan bahwa penggunaan LKPD berbasis $P O E$ berpengaruh signifikan terhadap hasil belajar peserta didik materi impuls dan momentum pada ranah kognitif maupun psikomotorik, dibuktikan dengan nilai signifikansi ranah kognitif maupun psikomotorik sebesar 0,000. Besarnya pengaruh penggunaan LKPD berbasis $P O E$ cukup tinggi, dengan nilai effect size (Cohen's $d$ ) sebesar 2,18; 1,34; dan 1,21 dengan kriteria keseluruhan besar. Sehingga dapat dikatakan bahwa penggunaan LKPD berbasis $P O E$ pada penelitian ini memiliki pengaruh yang besar terhadap peningkatan hasil belajar kognitif dan psikomotorik peserta didik.

Saran yang dapat disampaikan yaitu (1) guru sebaiknya menggunakan LKPD berbasis POE dalam pembelajaran di kelas untuk meningkatkan hasil belajar peserta didik, (2) melakukan persiapan yang matang dengan mempertimbangkan pengalokasian waktu pada setiap langkah-langkah pembelajaran $P O E$ apabila akan menggunakan LKPD dengan langkah-langkah $P O E$, (3) Membagi peserta didik dalam kelompok yang lebih kecil yaitu 5-6 orang dalam satu kelompok, (4) memberikan penguatan dan memotivasi peserta didik yang kurang aktif dalam pembelajaran agar lebih mampu melakukan prediksi dan eksplanasi terhadap masalah yang ada.

\section{DAFTAR PUSTAKA}

Astuti, D.P., Leonard, L., Bhakti, Y. B., \& Astuti, I. A. D. (2019). Developing Adobe Flash-based mathematics learning media for $7^{\text {th }}$-grade students of junior high school. Journal of Physics: Conf. Series 1188012098. http://dx.doi.org/10.1088/1742-6596/1188/1/012098

Astuti, M. R., Sulianto, J., \& Purnamasari, V. (2018). Keefektifan model predict-observeexplain terhadap kemampuan pemahaman konsep pada mata pelajaran IPA. Mimbar Sekolah Dasar, 4(3), 235. https://doi.org/10.17509/mimbar-sd.v4i3.7876

Badan Standar Nasional Pendidikan. (2010). Paradigma Pendidikan Nasional di Abad 21. Jakarta: BSNP, 1-59. 
Formatif: Jurnal Ilmiah Pendidikan MIPA

Vol. 9, No. 3, September 2019, pp. 219-228

p-ISSN: 2088-351X

e-ISSN: 2502-5457

DOI: http://dx.doi.org/10.30998/formatif.v9i3.3638

Berek, F. X. (2016). Concept enhancement of junior high school students in hydrostatic pressure and archimedes law by predict- observe- explain strategy. Jurnal Pendidikan IPA Indonesia, 5(2), 230-238. https://doi.org/10.15294/jpii.v5i2.6038

Cinici, A., \& Demir, Y. (2015). Teaching through cooperative POE tasks: A path to conceptual change. The Clearing House: A Journal of Educational Strategies, Issues and Ideas, 86(1), 1-10. https://doi.org/10.1080/00098655.2012.712557

Cohen, J. (1988). Statistical Power Analysis For The Behavioral Science (2nd ed.). New York: Lawrence Erlbaum Associates.

Erni, Napitupulu, M., \& Sakung, J. (2013). Pengaruh model POE (Predict-ObserveExplain) terhadap hasil belajar kimia pada kelas XI materi kelarutan dan hasil kali kelarutan di SMA Negeri 4 Pasangkayu. Jurnal Akademika Kimia, 2(2), 62-67.

Fadly, A. (2012). Peningkatan aktivitas dan hasil belajar siswa melalui model pembelajaran problem based learning (PBL) (Studi pada kelas $\mathrm{x}$ bisnis dan manajemen mata pelajaran kewirausahaan di SMK Mrdjuna 1 Malang). Jurnal Fakultas Ekonomi Universitas Negri Malang, 1-15.

Gustina, O., Fadiawati, N., Kadaritna, N., \& Diawati, C. (2013). Peningkatan keterampilan memprediksi dan penguasaan konsep pada materi termokimia melalui model siklus pembelajaran predict-observe-explain. Jurnal Pendidikan Dan Pembelajaran Kimia, 2(2). $\quad$ Retrieved from http://jurnal.fkip.unila.ac.id/index.php/JPK/article/view/1920/1164

Ipek, H. (2010). Using POE strategy to investigate student teachers' understanding about the effect of substance type on solubility. Procedia - Social and Behavioral Sciences, 2(2), 648-653. https://doi.org/10.1016/j.sbspro.2010.03.078

Keleş, E., \& Demirel, P. (2010). A study towards correcting student misconceptions related to the color issue in light unit with POE technique. Procedia - Social and Behavioral Sciences, 2(2), 3134-3139. https://doi.org/10.1016/j.sbspro.2010.03.477

Liew, C.-W., \& Treagust, D. F. (2004). The Effectiveness of predict-observe-explain tasks in diagnosing students' understanding of science and in identifying their levels of achievement. Annual Meeting of the American Educational Research Association., 224-234. Retrieved from http://eric.ed.gov/ERICWebPortal/contentdelivery/servlet/ERICServlet?accno=ED4 20715

Mahnun, N. (2012). Media pembelajaran (kajian terhadap langkah-langkah pemilihan media dan implementasinya dalam pembelajaran). An-Nida', 37(1), 27-35.

Mayasari, H., Syamsurizal, \& Maison. (2015). Pengembangan lembar kerja siswa (LKS) berbasis karakter melalui pendekatan saintifik pada materi fluida statik untuk sekolah menengah atas. Edu-Sains, 4(2), 30-36.

Meltzer, D. E. (2002). The relationship between mathematics preparation and conceptual learning gains in physics: A possible "hidden variable" in diagnostic pretest scores. American Journal of Physics, 70(12), 1259-1268. https://doi.org/10.1119/1.1514215

Permatasari, B., Nyeneng, I. D. P., \& Wahyudi, I. (2018). Pengembangan LKPD berbasis POE untuk pembelajaran fisika materi momentum dan impuls SMA. Jurnal Pembelajaran Fisika, 6(1), 70-81. Retrieved from http://jurnal.fkip.unila.ac.id/index.php/JPF/article/view/15461/11356

Puspitasari, R., Lesmono, A. D., \& Prihandono, T. (2015). Pengaruh model pembelajaran Poe (Prediction, Observation and Explanation) disertai media audiovisual terhadap keterampilan kerja ilmiah dan hasil belajar siswa dalam pembelajaran IPA-Fisika di SMP. Jurnal Pembelajaran Fisika, 4(3), 211-218. 
Formatif: Jurnal Ilmiah Pendidikan MIPA

Vol. 9, No. 3, September 2019, pp. 219-228

p-ISSN: 2088-351X

e-ISSN: 2502-5457

DOI: http://dx.doi.org/10.30998/formatif.v9i3.3638

Rifzal, I. L., Alkmam, \& Nurhayati. (2015). Pembelajaran IPA Terhadap Kompetensi Siswa Kelas VII SMPN 5 Padang Staf Pengajar Jurusan Fisika, FMIPA Universitas Negeri Padang, 6, 33-40.

Ristiyani, D., \& Yulianti, D. (2014). Pengembangan LKS fisika materi pemantulan dan pembiasan cahaya terintegrasi karakter dengan pendekatan saintifik. Unnes Physics Education Journal, 3(8), 688-693. https://doi.org/https://doi.org/10.15294/upej.v3i3.4321

Rosdianto, H., Murdani, E., \& Hendra. (2017). the Implementation of Poe (Predict Observe Explain) Model To Improve Student'S Concept Understanding on Newton'S Law. Jurnal Pendidikan Fisika, 6(1), 55. https://doi.org/10.22611/jpf.v6i1.6899

Sisdiknas. (2003). Undang Undang No 20 Tahun 2003 tentang Sistem Pendidikan Nasional.

Sutrisno, V. L. P., \& Siswanto, B. T. (2016). Faktor-faktor yang mempengaruhi hasil belajar siswa pada pembelajaran praktik kelistrikan otomotif SMK di Kota Yogyakarta. Jurnal Pendidikan Vokasi, 6(1), 112-120. Retrieved from https://journal.uny.ac.id/index.php/ jpv/article/viewFile/8118/6872

Yanti, Y. D., Arcat, \& Hardianto. (2013). Pengembangan lembar kerja siswa (LKS) matematika berbasis penemuan terbimbing untuk siswa kelas VIII sekolah menengah pertama pada materi kubus, balok, prisma dan limas, 3(1), 1-8.

Yulianti, D., Marfu'ah, S., \& Yulianto, A. (2015). Development of physics student work sheet (SWS) to build science process skill valued conservation. Jurnal Pendidikan Fisika Indonesia, 11(2), 126-133. https://doi.org/10.15294/jpfi.v11i2.26 
Formatif: Jurnal Ilmiah Pendidikan MIPA

Vol. 9, No. 3, September 2019, pp. 219-228

p-ISSN: 2088-351X

e-ISSN: 2502-5457

DOI: http://dx.doi.org/10.30998/formatif.v9i3.3638 